\title{
Metode-Metode Dalam Pembelajaran Keterampilan Bahasa Arab Reseptif
}

\author{
R. Umi Baroroh \\ UIN Sunan Kalijaga Yogyakarta, Indonesia \\ rumibaroroh32@gmail.com \\ Fauziyah Nur Rahmawati \\ UIN Sunan Kalijaga Yogyakarta, Indonesia \\ fauziyahrahma508@gmail.com
}

\begin{abstract}
:
There are four main components in learning Arabic language, as the basis .They are listening (istima), reading (qiroah), speaking (kalam), and writing skills (kitabah). Istima 'and qiroah skills are receptive skills. This research is aimed to find out how to choose suitable methods to be applied in Arabic learning in receptive skills. This research is library research (literature study) that relies on books or journals, and then the data was analyzed using the content analysis method. The findings of this study indicate that there are many methods in learning Arabic, including direct method, aAl-sam'iyah alsyafawiyah, qiroah, and teacher silent method. This research also discusses how to use a good method to make students do not find difficulties and boring in the learning and the aim learning is achieved. In selecting a method, the teacher should know how the students' condition and development.
\end{abstract}

Keyword: Learning Methods, Receptive Skills.

\section{Pendahuluan}

Bahasa merupakan suatu sistem yang arbitrer, yang digunakan untuk komunikasi dan tukar fikiran antar kelompok manusia tertentu. Bahasa arab adalah bahasa al-Quran, bahasa informasi dan bahasa komunikasi, dan sekaligus menjadi salah satu bagian dari bahasa internasional. Oleh karena itu mempelajari bahasa Arab sangatlah penting, dengan banyaknya sumber ilmu pengetahuan yang menggunakan bahasa Arab.

Ketika kita mempelajari bahasa Arab harus memiliki empat komponen keterampilan berbahasa yang harus dikuasai dengan baik bagi pembelajar bahasa Arab, yaitu ketrampilan mendengar (maharah istima), keterampilan berbicara (maharah kalam), ketrampilan membaca (maharah qiroah) dan keterampilan menulis (maharah kitabah). Setelah menguasai empat komponen keterampilan tersebut, maka pembelajaran lain akan berjalan dengan optimal. Akan tetapi banyak permasalahan yang muncul dalam pembelajaran bahasa Arab, diantaranya para pembelajar bahasa Arab yang menganggap bahwa mempelajari bahasa Arab itu sulit dan membosankan. dengan kesulitan inilah yang menjadi tantangan bagi para pemerhati pendidikan dan guru bahasa Arab untuk menentukan sebuah 
metode pengajaran yang tepat sehingga dalam pembelajaran bahasa Arab dapat tercipta suasana belajar yang menyenangkan, dan dapat menimbulkan perhatian dan motivasi belajar bahasa Arab bagi peserta didik.

Maka dalam pembelajaran bahasa Arab, disamping membutuhkan guru bahasa Arab yang kompeten dan ahli dalam bahasa Arab juga membutuhkan inovasiinovasi dalam pembelajaran bahasa Arab, sehingga peserta didik merasa tertarik ketika belajar bahasa Arab dan hendaknya guru Bahasa Arab mampu membuat siswa termotivasi dan bersemangat untuk belajar bahasa Arab. salah satu persoalan yang dihadapi oleh hampir setiap guru bahasa Arab adalah adanya citra yang muncul di kalangan peserta didik bahwa mempelajari bahasa Arab merupakan suatu mata pelajaran yang dianggap sulit. Dengan adanya permasalah yang telah dipaparkan kemudian terdapat salah satu inovasinya yaitu dengan dibutuhknnya sebuah metode dalam pembelajaran bahasa Arab. Metode menurut Sutomo (1993) merupakan suatu alat yang dipergunakan untuk mencapai suatu tujuan yang di kehendaki, sehingga semakin baik penggunaan metode mengajar memungkinkan keberhasilan dalam mencapai tujuan akan semakin mudah. Menurut Bisri Mustofa dan Abdul Hamid dalam metode itu terdapat cara dan sarana untuk menyajikan materi pelajaran, maka ketepatan dalam memilih metode sangat menentukan keberhasilan penggunaan metode pembelajaran tersebut. ${ }^{1}$

Pada metode pengajaran bahasa kedua (bahasa Arab) mulai sekarang ini mengalami perkembangan secara terus menerus, seiring dengan perkembangannya yang terjadi pada beberapa disiplin ilmu yang berkaitan erat dengan bahasa dan pengajaran, yang antara lain ilmu bahasa, ilmu pendidikan, dan ilmu jiwa. Lebih dari itu, hasil-hasil penelitian dalam bidang-bidang pengajaran bahasa itu sendiri akan memberikan kontribusi kepada lahirnya suatu metode baru dalam pengajaran bahasa Arab.

Dalam menetapkan suatu metode pengajaran, seorang guru harus menyesuaikan dengan tujuan pembelajaran yang telah ditentukan. Setelah guru menentukan tujuan pembelajaran, maka persoalan selanjutnya adalah guru menetapkan metode agar tujuan yang telah ditentukan dapat tercapai secara optimal. Kemudian metode pembelajaran yang baik adalah metode yang mampu membawa siswa untuk mencapai suatu tujuan pendidikan dan melatih kemampuan siswa dalam berbagai kegiatan. Banyak sekali macam metode-metode dalam pengajaran bahasa Arab diantaranya metode tersebut adalah metode langsung, metode Al-sam'iyah Al-Syafawiyah, metode qiroah, dan metode Guru Diam. Semua metode-metode tersebut cocok untuk pembelajaran bahasa Arab pada keterampilan istima dan keterampilan qiroahatau disebut juga dengan keterampilan reseptif. Keterampilan reseptif ini merupakan salah satu jenis keterampilan berbahasa arab yang bersifat penerimaan dan penyerapan. Farhatul Atiqoh mengatakan bahwasanya Keterampilan berbahasa reseptif adalah terampil dan mampu menerjemahkan kembali kode-kode bahasa menjadi sebuah makna

\footnotetext{
${ }^{1}$ Bisri Musthofa dan Abdul Hamid, Metode Dan Strategi Pembelajaran Bahasa Arab (UIN Maliki Press,
} 2012), 43. 
dalam komunikasi baik secara lisan maupun secara tulisan. ${ }^{2}$ Di dalam keterampilan inilah siswa dituntut untuk mampu menyerap materi yang disampikan oleh gurunya. Akan tetapi dalam kenyataannya masih banyak siswa yang sukar dalam mempelajari bahasa Arab dan menganggap bahwa bahasa Arab itu sulit untuk dipelajari, padahal dalam pembelajarannya biasanya guru sudah menyiapkan suatu metode agar peserta didik tidak bosan dan mudah dalam mempelajarinya.

Oleh karena itu, pembahasan tentang metode-metode pembelajaran bahasa Arab pada keterampilan reseptif ini menghendaki penelitian secara mendalam dengan mengkaji berbagai literatur tentang macam metode-metode dalam keterampilan reseptif, agar dalam pembelajaran bahasa Arab peserta didik tidak merasa bosan dan sulit dalam mempelajarinya. Adapun macam-macam metode dalam pembelajaran reseptif ini belum terlalu banyak dibahas, bagaimana cara mengajarkan keterampilan istima dan qiroah dengan menggunakan metode yang cocok.

Berdasarkan literatur review peneliti melakukan penelitian terdahulu menunjukkan bahwa selama ini penelitian tentang metode-metode pada keterampilan reseptif ini belum begitu banyak yang membahasnya.tidak bisa dipungkiri bahwa metode-metode pembelajaran bahasa Arab sangat berpengaruh terhadap pembelajaran peserta didik. Misalnya pada penelitiannya Muhammad Arif yang berjudul Metode Langsung (Direct Method) dalam Pembelajaran Bahasa Arab yang di dalam menerangkan tentang bagaimana langkah-langkah penerapan metode langsung dalam pembelajaran bahasa Arab. akan tetapi yang penulis lakukan tidak hanya berfokus pada satu metode saja, melainkan berbagai macam metode yang sesuai pada keterampilan istima dan qiroah pada tingkatan peserta didik.

Selain itu, terdapat penelitian dari Mohammad Makimmudin dengan judul Metode Pembelajaran Bahasa Arab, dalam pembelajaran ini didalamnyaa menerangkan berbagai metode-metode akan tetapi dalam penggunaan metode tersebut masih umum untuk maharah atau keterampilan manapun. ${ }^{3}$ Akan tetapi dalam tulisan ini penulis lebih menspesifikkan metode-metode ini untuk keterampilan reseptif atau keterampilan istima dan qiroah.

Berdasarkan beberapa penelitian tersebut belum ada yang membahas secara detail mengenai metode-metode pembelajaran bahasa Arab pada keterampilan reseptif. Oleh karena itu, tulisan ini bertujuan untuk membahas macam-macam metode pada keterampilan reseptif, agar dalam pembelajaran guru bisa menggunakan metode-metode tersebut sesuai dengan keterampilan bahasa Arab. kemudian hasil penelitian ini diharapkan bisa menjadi rujukan untuk diterapkan kepada guru dalam pembelajaran bahasa Arab diberbagai lembaga pendidikan dengan memperhatikan tingkatan peserta didik.

2 Farhatul Atiqoh, Teknik Maudhu Usbuiy Sebagai Alternatif Untuk Meningkatkan Penguasaan Keteramilan Reseptif Dan Produktif Bahasa Arab, (Universitas Negeri Malang, 2018), 200.

${ }^{3}$ Mohammad Makinuddin, Metode Pengajaran Bahasa, (MIYAH : Jurnal Studi Islam, 2017). 43 
Penelitian ini merupakan penelitian studi pustaka (library research), yang menurut Sukardi yaitu penelitian yang pengumpulan datanya dilakukan diperpustakaan dengan didasarkan atas pembacaan terhadap beberapa literatur yang dapat memberikan informasi serta memiliki relevansi dengan topik penelitian. ${ }^{4}$ Sumber data diambil dari eksplorasi literatur kepustakaan terkait topik penelitian, yaitu metode-metode pembelajaran bahasa arab reseptif, dan kemudian dianalisis secara mendalam dengan cara reduksi data, penyajian data dan penarikan kesimpulan.

Dalam penelitian yang penulis lakukan terdapat dua sumber data, yaitu sumber data primer dan sumber data sekunder. Sumber data primer dalam penelitian ini adalah buku metode dan strategi pembelajaran bahasa Arab karya Bisri Musthofa dan Abdul Hamid. Adapun sumber data sekunder adalah buku Syaiful Mustofa yang berjudul Strategi Pembelajaran bahasa Arab Inovatif dan buku karangan Munir yang berjudul Perencanaan Sistem Pengajaran Bahasa Arab serta berbagai artikel-artikel jurnal terkait metode pembelajaran bahasa Arab.

\section{HASIL DAN PEMBAHASAN}

\section{Metode Pembelajaran}

Webster (1980) mengatakan metode berasal dari bahasa inggris yaitu method yang berarti suatu cara kerja yang sistematis dan umum seperti cara kerja ilmu pengetahuan dan merupakan jawaban atas pertanyaan. Sedangkan menurut Abudin Nata di dalam bahasa arab metode diungkapkan dalam berbagai kata yaitu: Al-Thariqah yang berarti jalan kemudian manhaj yang berarti sistem dan al-wasilah yang berarti perantara atau mediator. ${ }^{5}$ Dalam hal ini kata yang sesuai digunakan adalah Al-Thariqah. Ali Bin Muhammad alJurjani mengatakan طريقة berarti cara yang tepat yang dapat digunakan untuk mencapai suatu tujuan.

Syaiful mustofa menjelaskan Metode secara terminologi merupakan cara mengajar yang digunakan oleh pengajar dalam sebuah proses pembelajaran bahasa agar tercipta tujuan yang ingin dicapai. ${ }^{6}$ Kemudian menurut Suyono metode adalah seluruh perencanaan dan prosedur maupun langkah-langkah kegiatan pembelajaran termasuk pilihan cara penilaian yang akan dilaksanakan. ${ }^{7}$ Dari pengertian di atas dapat disimpulkan bahwa pengertian metode adalah segala hal yang termuat dalam setiap proses pembelajaran pada diri siswa dalam upaya untuk mencapai suatu tujuan.

\footnotetext{
4 Sukardi, Metodologi Penelitian Pendidikan: Kompetensi Dan Praktiknya (Jakarta, Bumi Aksara, 2010). 38

${ }^{5}$ Abudin Nata, Filsafat Pendidikan Islam (Jakarta: Logos Wacana Ilmu, 1997). 60

${ }^{6}$ Syaiful Musthofa, Strategi Pembelajaran Inovatif (UIN Maliki Press, 2011). 135

7 Suyono, Belajar Dan Pembelajaran (Bandung, Remaja Rosdakarya, 2911). 32
} 
Sebelum kita menentukan sebuah metode kita harus mengetahui dan memperhatikan terlebih dahulu tingkat perkembangan siswa, kondisi siswa, dan memperhatikan perbedaaan kemampuan siswa dalam menyajikan materi yang akan kita ajarkan. Kita harus melihat pula keadaan siswa, dan seorang guru harus tepat dalam memilih sebuah metode dengan itu akan memudahkan guru untuk menentukan keberhasilan seorang muridnya. Syaiful Bahri dan Aswan mengatakan bahwa penggunaan metode yang tidak sesuai dengan tujuan pengajaran akan menjadi kendala dalam mencapai tujuan yang telah dirumuskan (ditetapkan). ${ }^{8}$ Dengan demikian bahwa setiap metode tertentu akan senantiasa berkaitan dengan ketentuan-ketentuan tentang pilihan materi atau seleksi, gradasi, presentasi, dan repetisi atau latihan-latihan dengan pengulangan materi dalam proses pembelajaran. Syaiful Mustofa mengatakan metode itu merupakan sebuah sistem dari berbagai komponen yang ada dan saling berkaitan. ${ }^{9}$

Sri Dahlia mengatakan apabila metode yang digunakan untuk pembelajaran tidak sesuai dengan kemampuan siswa, maka yang terjadi adalah mereka tidak dapat mengikuti pembelajaran dengan baik dan pembelajaran tersebut tidak membuahkan hasil apapun. ${ }^{10}$ Karena metode merupakan kunci utama keberhasilan pembelajaran, dengan adanya metode akan sangat membantu siswa dalam memahami pelajaran tersebut dan akan memudahkan guru dalam menyampikan pelajarannya. Apabila seorang guru mempunyai pengetahuan yang sangat tinggi dalam penguasaan materinya akan tetapi guru tersebut tidak mempunyai metode yang baik kemungkinan pembelajaran tersebut akan kurang baik dan membosankan. Dalam penggunaan metode pula guru harus menyesuaikan kondisi kelas dan suasana kelas, karena jumlah siswa akan mempengaruhi dalam penggunaan metode.

\section{Keterampilan Reseptif}

Ketika kita mempelajari bahasa arab pasti kita akan dihadapkan dengan komponen keterampilan berbahasa. Komponen keterampilan berbahasa memiliki hubungan yang sangat erat antara satu dengan yang lainnya. Dalam mempelajari bahasa arab, pasti akan dihadapkan dengan komponen penting keterampilan berbahasa. Dengan itu komponen-komponen tersebut harus dikuasai oleh siswa yang sedang melakukan pembelajaran bahasa arab agar pembelajarannya mudah untuk dipahaminya.

Muljanto mengatakan berbahasa merupakan gabungan yang berurutan antara dua proses dari dua aspek. Kemudian aspek tersebut pada dasarnya dapat digolongkan menjadi dua bagian yaitu: kemampuan reseptif dan

\footnotetext{
8 Syaiful Bahri, Strategi Belajar Mengajar (Jakarta: Rineka Cipta, 2010). 73

9 Syaiful Musthofa, Strategi.........., 145

10 Sri Dahlia, 'Urgensi Metode Qiroah Dalam Pembelajaran Bahasa Arab Di PTAI, Arabia, 2013. 14
} 
kemampuan produktif.11 Aspek pertama, proses produktif yang artinya proses yang berlangsung pada si pembicara yang menghasilkan kode-kode bahasa yang bermakna dan berguna. Kemudian aspek yang kedua proses reseptif yang artinya proses yang berlangsung pada diri si pendengar yang menerima kodekode bahasa yang bermakna dan berguna yang disampikan oleh pembicara melalui alat artikulasi dan diterima melalui pendengaran.

Dari pengertian diatas, empat komponen tersebut bisa dikelompokkan menjadi dua, pertama ketrampilan produktif, yaitu yang menghasilkan keterampilan seperti keterampilan berbicara (kalam) dan ketrampilan menulis (kitabah). Kemudian yang kedua, keterampilan reseptif yaitu keterampilan untuk pemahaman, yang berisi ketrampilan menyimak (istima') dan ketrampilan membaca (qiroah). Empat komponen diatas merupakan komponen yang sangat penting yang harus dikuasai pelajar dalam pembelajaran bahasa arab, agar pembelajarannya berlangsung secara baik. Akan tetapi disini penulis akan lebih memfokuskan pada keterampilan reseptif saja.

Keterampilan reseptif menurut farhatul atiqoh adalah salah satu jenis keterampilan berbahasa arab yang bersifat menerima dan menyerap. Keterampilan berbahasa reseptif ini mampu menerjemahkan kembali kode-kode bahasa agar menjadi sebuah makna untuk berkomunikasi, baik itu berbentuk tulisan maupun berbentuk lisan. ${ }^{12}$ Dalam ketrampilan reseptif ini siswa dituntut untuk untuk bisa menerima dan menyerap materi yang telah disampikan oleh gurunya. Kemudian ketrampilan ini mencakup dua aspek ketrampilan yang pertama ketrampilan istima (mendengar) dan ketrampilan qiroah (membaca).

Menurut Zulhannah di dalam Ahmad Jamhuri Sebagai salah satu kompetensi reseptif, keterampilan menyimak menjadi unsur yang harus lebih dikuasai oleh para pelajar. ${ }^{13}$ Menyimak menurut Tarigan adalah suatu proses kegiatan mendengarkan lambang-lambang lisan dengan penuh perhatian, pemahaman, apressiaasi, serta interpretasi untuk memperoleh suatu informasi, menangkap isi atau pesan serta memahami makna komunikasi yang telah disampaikan oleh pembicara melalui ujaran atau bahasa lisan. ${ }^{14}$ Interpretasi terhadap terminologi menyimak yaitu seseorang yang memfokuskan pikirannya untuk memperhatikan sesuatu yang sedang diucapkan oleh lawan bicaranya, dengan tendensi memahami konten atau isi pembicaranya.

Tujuan utama dalam keterampilan istima' menurut Qomi Akid dalam Jamhuri adalah menguasai dari apa-apa yang didengar baik secara ma'rify, wijdany, maupun suluky, bahwa dalam pembelajaran guru memiliki peran yang sangat besar dalam mensukseskan anak didiknya serta menanamkan keterampilan pembelajaran istima'. Dalam proses penanaman keterampilan

\footnotetext{
11 Muljanto, Pedoman Pengajaran Bahasa Asing (Surabaya CV. Ilmu Surabaya, 1975), 70

12 Farhatul Atiqoh, Teknik Maudhu Usbuiy Sebagai Alternatif Untuk Meningkatkan Penguasaan ......, 200

13 Jamhuri, Ketimpangan Komptenesi Santri Dalam Berbahasa Arab (Studi Analisis Pembelajaran Keterampilan Bahasa Arab Reseptif Dan Produktif Di Pondok Pesantren AL-Baqiyatus Shalihat (UIN Sunan Kalijaga, 2018), 39

14 Tarigan, Berbicara Sebagai Suatu Keterampilan Berbahasa (Bandung: PT.Angkasa, 2008), 58
} 
mendengar kepada anak didik tidak akan tumbuh kecuali dengan adanya interaksi yang baik antara guru dan murid yang dengan hal itu akan menjadi langkah awal kesuksesan guru dalam mengajarkan istima'. Kemudian menurut Madzkur tujuan pembelajaran istima secara lebih komprehensif untuk semua tingkatan pembelajar bahasa Arab yaitu: mengidentifikasi bunyi ujaran (kalimat, kata, dan huruf), mengkategorisasi berbagai ujaran bahasa Arab, menentukan gagasan utama dari teks yang di dengar, menangkap kesimpulan dari keseluruhan teks yang didengar, menganalisis kebenaran kandungan teks yang di dengar. Apabila keenam tujuan tersebut diklasifikasikan berdasarkan tingkatan pembelajaran bahasa Arab, mka tujuan nomer satu dan dua dapat dikategorikan sebagai tujuan pembelajaran istima pada tingkat mubtadi, kemudian tujuan ketiga dan keempat untuk tingkatan mutawasith, sedangkan tujuan kelima dan keenam untuk tingkatan mutaqodim.

Kemudian pada keterampilan selanjutnya yaitu keterampilan Qiroah (membaca). Menurut Mustofa dan Hamid keterampilan qiroah (membaca) merupakan kegiatan yang meliputi semua bentuk-bentuk berfikir, memberi penilaian, memberi keputusan, menganalisis dan mencari pemecahan masalah. ${ }^{15}$ Membaca merupakan sumber segala pengetahuan, kemudian membaca merupakan materi terpenting diantara materi-materi pelajaran lainnya. Membaca adalah kegiatan untuk mengetahui makna dari apa yang telah tertulis di dalam teks. Kegiatan membaca termasuk aktivitas yang tidak mudah dan rumit untuk dilakukan, karena membaca bergantung pada ketrampilan berbahasa dan tingkat penalarannya. Abdul Rahman mengatakan Semakin giat dan serius seorang peserta didik dalam mengikuti pembelajaran Qiroah, maka semakin besar pula peluang bagianya untuk memiliki keterampilan berbahasa yang baik. ${ }^{16}$ Seseorang tidak akan bisa unggul dalam materinya atau pembelajarannya apabila seseorang itu tidak bisa dalam membaca. Oleh karena itu membaca merupakan sarana penting untuk mencapai tujuan pembelajaran bahasa. Kemudian terdapat tujuan dalam pembelajaran qiroah menurut Anwar dalam Abdul Rahman adalah untuk menumbuhkan dan mengembangkan kemahiran membaca. Menurut Hasan Saefulloh terdapat tujuan pengajaran qiroah pada tingkat mubtadi (pemula) yaitu terfokus pada pencapaian kompetensi pengucapan yaitu mengenali lambang bunyi bahasa dan melafalkannya dengan baik dan benar sesuai dengan aturan tata bahasa Arab. ${ }^{17}$ artinya untuk tingkatan dasar itu lebih memprioritaskan pada aspek kelancaran membaca dengan makhroj yang benar.

\footnotetext{
15 Abdul Hamid dan Musthofa, Metode dan Strategi....., 42

16 Abdur Rahman, 'Keterampilan Membaca Dan Teknik Pengembanganya Dalam Pembelajaran Bahasa Arab', Diwan: Jurnal Bahasa Dan Sastra Arab, 2017, 59

17 Hasan Syaifullah, Teknik Pembelajaran Keterampilan Bahasa Arab (Cirebon: Nurjati Press, 2012), 27
} 


\section{Macam-macam metode pembelajaran bahasa Arab pada keterampilan istima'}

\section{a. Metode langsung}

1. Latar belakang metode langsung

Metode langsung muncul akibat ketidakpuasan terhadap hasil pengajaran bahasa dengan metode konvensional dikaitkan dengan tuntutan kebutuhan nyata di masyarakat. Karena tuntutan itulah para ahli bahasa mencetuskan metode baru yang disebut dengan "metode langsung". Diantara para ahli itu adalah Francois Gouin (1880-1992), sekarang guru bahasa latin yang mengembangkan metode berdasarkan pengamatannya pada penggunaan bahasa ibu oleh anak-anak. Ahmad Fuad Effendy mengatakan Metode ini memperoleh popularitas pada awal abad ke-20 di eropa dan Amerika.pada waktu yang sama, metode ini juga digunakan untuk pengajaran bahasa arab, baik di Arab maupun islam di Asia, termasuk di Indonesia. ${ }^{18}$

Acep Hermawan mengatakan pembelajaran bahasa arab bagi non Arab dimulai dari pertama kali pada abad ke-17, ketika Bahasa Arab mulai diajarkan di Universitas Cambridge Inggris. Sementara di Amerika, perhatian terhapad bahasa Arab dan pembelajarannya baru dimulai pada tahun 1947 di sekolah-sekolah tentara Amerika. Di Mesir, terdapat banyak pusat pembelejaran Bahasa Arab, ditandai dengan banyaknya proyek pengembangan Bahasa Arab. ${ }^{19}$ Pada setiap pusatpusat pembelajaran bahasa ini, dipastikan ada proyek pengembangan bahasa arab lengkap dengan tujuan-tujuan khusus, sejumlah perencanaan dan materi-materinya.

Kemudian Bisri Mustofa dan Abdul Hamid menjelaskan metode langsung lahir sebagai reaksi terhadap penggunaan metode al-qowaid watarjamah yang mengajarkan bahasa seperti bahasa yang mati. Dan sebelumnya sejak tahun 1850 telah banyak muncul propaganda yang mengkampanyekan agar menjadikan pengajaran bahasa asing itu hidup, menyenangkan dan efektif. Propaganda ini menuntut adanya perubahan yang mendasar dalam metode pengajaran bahasa asing sehingga kemudian secara cepat lahirlah metode pembelajaran baru yang disebut dengan metode langsung. ${ }^{20}$

2. Ciri-ciri metode langsung menurut Abdul Hamid dan Bisri Mustofa yaitu: ${ }^{21}$

a. Tujuan dasar yang diharapakan oleh metode ini adalah mengembangkan kemampuan siswa untuk berfikir dengan bahasa Arab bukan dengan bahasa ibu siswa

\footnotetext{
18 Ahmad Fuad Efendy, Metodologi Pengajaran Bahasa Arab (Malang: Misykat, 2012), 47

19 Acep Hermawan, Metodologi Pembelajaran Bahasa Arab (Bandung, Remaja Rosdakarya, 2011), 80

${ }^{20}$ Bisri Musthofa dan Abdul Hamid, Metode Dan Strategi Pembelajaran......., 86

${ }^{21}$ Bisri Musthofa dan Abdul Hamid, Metode dan Strategi......, 105
} 
b. Hendaknya pembelajaran bahasa Arab dengan menggunakan bahasa Arab tidak digunakan lain sebagai medianya.

c. Teks Arab tidak disajikan kepada siswa sebelum mereka mengenal suara, kosakata serta susunan yang ada di dalamnya. Dan juga siswa tidak menulis teks Arab sebelum mereka bisa membaca dengan baik serta memahaminya.

3. Kelebihan pada metode langsung adalah:

a. Membangkitkan semangat para guru Bahasa Arab untuk menggunakan bahasa Arab sebagai akal komunikasi yang dapat membantu tercapainya maharah al-istima'

b. Memotivasi siswa untuk senantiasa berpikir tentang bahasa Arab sehingga tidak terjadi percampuran dengan bahasa ibu

c. Memotivasi siswa untuk dapat menyebutkan dan mengerti kata-kata dan kalimat dalam bahasa asing yang diajarkan, apalagi dengan bantuan alat peraga.

d. Memudahkan siswa menangkap simbol-simbol bahasa asing dengan kata-kata sederhana dan bahasa sehari-hari

e. Memberikan siswa pengalaman langsung dan praktis, sekalipun mungkin kalimat yang diucapkan belum dipahami sepenuhnya

f. Melatih alat ucap siswa dengan sering mendengar dan mengucapkan kata-kata dan kalimat.

4. Kekurangan pada metode langsung menurut Abdul Hamid adalah: ${ }^{22}$

a. Harus membutuhkan guru yang benar-benar terampil dan fasih dalam berbahasa Arab

b. Siswa lemah dalam kemampuan membaca

c. Teknik yang digunakan pada metode langsung ini cenderung membosankan

d. Sukar menyediakan berbagai kegiatan yang menarik dan bersifat situasi sebenarnya di dalam kelas

e. Hanya dapat diterapkan pada kelompok kecil

Menurut Munir Metode langsung ini berasumsi bahwa belajar bahasa arab yang baik yaitu belajar secara langsung dengan menggunakan bahasa secara maksimal dalam berkomunikasi. Metode langsung dalam ketrampilan istima' ini adalah dengan memberikan contoh secara langsung kata-kata bahasa arab yang mengandung bunyi, baik yang berharokat fathah, kasroh, dhomah maupun yang berharokat sukun. ${ }^{23}$ Kemudian metode ini menenkanka pada latihan-latihan mendengarkan bunyi-bunyi huruf bahasa arab dan pada setiap pembelajaran, walaupun ketika mengajarkan materi lainyanya yang berkaitan dengan istima.

22 Abdul Hamid, Metode dan Strategi, 107

${ }^{23}$ Munir, Perencanaan Sistem Pengajaran Bahasa Arab (Jakarta PT.Fajar Intrapratama Mandiri, 2017), 69 
Kemudian Anwar Abdur rohman menjelaskan metode langsung sebenarnya berdasarkan konsep Jacob Gouin bahwa pembelajaran bahasa perlu dilakukan dengan dramatisasi dan peragaan dengan menggunakan prinsp-prinspi psikologi modern seperti asosiasi, visualisasi, panca indra, dan hal-hal yang menarik, belajar melalui permainan dan aktivitas keseharian yang dikenal oleh anak didik. Karena menurut Gouin dalam bukunya Imam Makhruf kalimat adalah unit bahasa yang fundamental yang setiap kalimat harus dihubungkan dengan kalimat lainnya untuk membentuk satu rangkaian. ${ }^{24}$ Oleh karena itu pembelajaran bahasa sebagai bahasa kedua (bahasa Arab) harus lebih seperti pembelajaran pada bahasa yang pertama, Ketika mulai pembelajaran dimulailah dengan adanya dialog-dialog agar peserta didik lama kelamaan akan merasa terbiasa dengan menggunakan bahasa kedua.

Dalam praktek belajar dan mengajar bahasa arab pada metode langsung ini, pertama: hendaknya guru mengenalkan bunyi-bunyi bahasa arab dan memperdengarkan ujaran-ujaran bahasa arab baik yang berbentuk kata-kata maupun kalimat. Kedua: guru memberikan tanya jawab kepada murid dari kata yang sederhana seperti menanyakan bagaimana, siapa, kapan dan lain sebagainya sesuai dengan tingkat kesulitan materi pelajaran yang berkaitan dengan kata yang telah disajikan. Ketiga: setelah mengetahui siswa telah menguasai materi yang telah disajikan tadi, kemudian siswa diminta untuk membuka teks dan kemudian membacanya. Keempat: siswa kemudian diberi soal dan menjawabnya secara lisan. Kegiatan ini sangat bermanfaat bagi siswa. Dengan ini siswa lama-lama akan tersebiasa mendengarkan kalimat atau bunyi-bunyi bahasa arab secara langsung. Kemudian setelah mereka sering mendengar kalimat atau kata-kata bahasa arab mereka dengan sendirinya akan menganggap bahasa arab dikalangan mereka sudah tidak asing lagi.

Dalam penggunaan metode langsung ini guru dapat menggunakannya pada semua tingkatan seperti tingkat mubtadi, mutawasith, dan mutaqodim. Akan tetapi yang membedakan pada tingkatan tersebut adalah tujuan, langkah-langkahnya dan prinsipprinspi pembelajaranya. Tetapi langkah-langkah diatas cocok dipakai pada tingkat mutawasith. Karena dalam tingkat mutawasit tersebut peserta didik harus sudah mempunyai bekal terlebih dahulu dalam pengajaran bahasa arab, beda dengan tingkat mubtadi, tingkat mubtadi itu dalam pembelajaran bahasa arab dia benar-benar dari awal atau biasanya dalam pembelajaranya mengenal huruf-huruf arab terlebih dahulu. Akan tetapi pada tingkat mutawasith ini peserta didik sudah mengenal bunyi bahasa arab dalam bentuk kata maupun kalimat.

24Imam Makhruf, Strategi Pembelajaran Bahasa Arab (Needs Press, 2009), 52 
Semi menyatakan dalam Ahmad Fuad bahwa metode langsung menghendaki agar peserta didik langsung diajak menggunkan bahasa yang bersangkutan, sebagaimana anak mempelajari bahasa ibunya. Dalam proses pembelajaran bahasa arab harus bermula dari pengenalan benda-benda dan perilaku yang ada di sekeliling pembelajar, misalnya benda-benda yang ada di dalam kelas. Ketike proses pembelajaran berlangsung, peserta didik mengkomunikasikan hal yang bisa dilihat dengan menggunakan bahasa arab .

\section{b. Metode audiolingual (Al-Thariqah Al-Sam'iyah Al-Syafawiyah)}

1. Latar belakang metode audiolingual

Metode audiolingual muncul akibat dari besarnya perhatian yang diberikan kepada pengajaran bahasa asing di Amerika Serikat pada tahun 1950-an. Istilah audiolingual ini diciptkan oleh Profesor Nelson Brooks pada tahun 1964-an menuntut perubahan pengajaran bahasa dari suatu seni menjadi suatu ilmu, yang akan memudahkan para pembelajar memperoleh penguasaan bahasa asing secara efektif dan efisien.

Bisri mustofa dan Abdul hamid mengatakan metode ini telah diterima secara luas bagi pengajaran bahasa asing, diperguruanperguruan tinggi Amerika Utara. Metode ini memberikan dasar metodologis bagi bahan-bahan pengajaran bahasa-bahasa asing di tingkat perguruan tinggi di Amerika Serikat dan Kanada. Tetapi metode audiolingual ini sempat mengalami kemuduran pada akhir 1960-an, tetapi metode audiolingual beserta materi-materinya yang berdasarkan prinsip-prinsip audiolingual tetap terpakai secara luas sampe sekarang ini. ${ }^{25}$

2. Ciri-ciri penggunaan metode Al-Sam'iyah dan Al-Syafawiyah yaitu:

a. Metode ini berangkat dari gambaran bahwa bahasa adalah seperangkat simbol-simbol suara yang dikenal oleh anggota masyarakat untuk mengadakan komunikasi di antara mereka. Maka tujuan pokok pengajaran bahasa Arab adalah memberi bekal kemampuan bagi selain penutur Arab agar mampu berkomunikasi aktif dengan penutur Arab dengan berbagai ketrampilan dan dalam berbagai situasi

b. Guru dalam mengajarkan ketrampilan bahasa mengikuti urutan asli pemerolehan bahasa pertama yaitu dari ketrampilan mendengar dulu kemudian menirukan bicara orang-orang sekitar dan mengucapkan kata-kata, membaca dan terakhir menulisnya.

3. Kelebihan metode Al-Syam'iyah Al-Syafawiyah (audiolingual):

a. siswa akan memiliki pelafalan bahasa yang bagus

b. dapat diterapkan pada tingkat mutawasith

c. memberi banyak latihan dan praktik dalam aspek ketrampilan menyimak dan berbicara

${ }^{25}$ Bisri Musthofa dan Abdul Hamid, Metode Dan Strategi......, 60 


\section{d. siswa dapat berkomunikasi secara lisan dengan baik \\ e. suasana kelas akan hidup karena siswa aktif}

4. Kekurangan metode Al-Syam'iyah Al-Syafawiyah (audiolingual) menurut Mohammad Makimuudin sebagai berikut:26

a. respon siswa mekanistik, sering tidak mengetahui atau memikirkan makna ujaran yang telah diucapkan

b. keaktifan siswa dalam kelas adalah semu, karena mereka hanya merespon rangsangan guru

c. latihan-latihan pola bersifat manipulatif, tidak kontekstual dan tidak realistik

Menurut Suja'i metode Al-Syamiyyah Al-Syafawiyah (audiolingual) berasal dari bahasa Arab "Sam'iyyah" yang artinya menyimak, maksudnya dalam proses belajar bahasa asing dari kosakata demi kosakata, dan dari kalimat demi kalimat. ${ }^{27}$ Oleh karena itu ketika mendengar percakapan dengan runtutan kalimat dia tidak langsung paham secara spontan akan tetapi melalui proses berfikir dari kalimat demi kalimat dalam otaknya untuk memahami. Sedangkan "Al-Syafawiyah" berasal dari bahasa arab yang artinya berbicara atau lisan. Maksudnya kemampuan menyampaikan pikiran sangat penting sekali dalam penguasaan bahasa, maksud dari berbicara adalah kemampuan bahasa yang berkembang pada kehidupan manusia, yang hanya didahului oleh keterampilan menyimak.

Dalam praktek belajar dan mengajar bahasa arab pada metode audiolingual atau bisa juga disebut metode as-samiyyah as-syafawiyah. menurut Alvia Putri langkah-langkah penyajiannya sebagai berikut, pertama: guru menyajikan sebuah dialog atau bacaan pendek, kemudian guru membaca berulang-ulang dan siswa menyimak teks bacaan tersebut. Kedua: siswa menirukan dan menghafalkan dialog atau bacaan pendek, dengan teknik menirukan bacaan guru kalimat per kalimat secara klasikal, sambil menghafalkan kalimat-kalimat tersebut. Ketiga: menyajikan polapola kalimat yang terdapat dalam dialog atau bacaan pendek, terutama yang dianggap sukar, karena terdapat struktur dalam bahasa ibu pelajar. Ini dilakukan dengan teknik dari yang umumnya bersifat mekanis. Keempat: dramatisasi dialog atau bacaan pendek yang sudah dilatihkan. Pelajar memeragakan atau mendramatisasikan dialog yang sudah dihafalkan didepan kelas secara bergantian. Kelima: guru meminta siswa untuk membuat kalimat-kalimat lain yang sesuai dengan pola-pola kalimat yang sudah dipelajarinya. ${ }^{28}$

Metode al-Thariqah al-Sam'iyah al-Syafawiyah (audiolingual) ini sering digunakan oleh seorang guru dalam proses pembelajaran. Kemudian dalam metode ini cocok digunakan peserta didik pada tingkat mutawasith dan

26 Muhammad Makimmudin, Metode Pengajaran Bahasa......, 47

${ }^{27}$ Suja'i, Inovasi Pembelajaran Bahasa Arab (Semarang: Walisongo Press, 2008), 64

28 Alvia Putri Prima Sari, 'Tinjauan Terhadap Metode Pembelajaran Bahasa Arab: Metode QawaidE Terjemah, Metode Langsung, Metode Audiolingual dan MetodeGabungan, (Tarbiyatuna, 2018), 117 
tingkat mutaqodim karena apabila metode ini diterapkan pada tingkat mubtadi' peserta didik akan kesulitan dalam mempelajari bahasa Arab. Karena pada tingkatan ini peserta didik sudah diminta untuk membuat kalimat dari apa yang telah dipelajarinya. Akan tetapi dalam pembelajaran bahasa Arab menggunakan al-Thariqah al-Syam'iyah al-Syafawiyah terkadang guru menemukan fenomena dalam pembelajarannya siswa hanya sibuk mengobrol dengan teman sebangkunya, dengan itu hendaknya guru lebih memperhatikan siswanya lagi ketika pembelajaran sedang berlangsung.

\section{Macam-macam Metode Pembelajaran Bahasa Arab pada Keterampilan Qiroah}

\section{a. Metode membaca (thariqah al-qiroah)}

1. latar belakang metode qiroah

Menurut Nazri Syakur bahwa penerapan metode langsung di Amerika pada perempat pertama abad dua puluh tidak semulus seperti di Eropa. Hal itu karena, tidak seperti di Eropa, di Amerika seseorang sulit memperoleh guru-guru bahasa berbahasa asli. Lebih dari itu lembaga-lembaga pendidikan di Amerika secara berkeyakinan kuat bahwa pendekatan membaca (reading approach) untuk pembelajaran bahasa kedua lebih berguna dari pada pendekatan berbicara (oral approach). Coleman meyakinkan kepada guru bahwa mengajarkan bahasa kedua dengan pendekatan berbicara itu tidak praktis, maka hendaknya guru menjadikan membaca sebagai fokus penekanan dan perhatian. ${ }^{29}$

Sejak tahun 1929 metode membaca mulai digunakan di sekolahsekolah menengah maupun perguruan tinggi di seluruh Amerika Serikat, dengan tujuan memberi siswa dan mahasiswa kemampuan untuk memahami teks ilmiah yang mereka perlukan dalam studi mereka. Kemudian metode ini berawal dari sebuah keyakinan, bahwa membaca adalah awal dari segala pengetahuan, karena hampir seluruh ilmu pengetahuan tertulis dalam sebuah buku, maka dari itu metode membaca ini pelajar akan bisa menguasai seluruh kemahiran dalam berbahasa.

2. Ciri-ciri penggunaan metode Qiroah yaitu:

a. Biasanya metode ini memulai dengan memberi latihan sebentar memberikan latihan kepada siswa tentang ketrampilan bertutur kemudian mendengarkan beberapa kalimat sederhana dan mengucapkan kata-kata serta kalimat hingga siswa mampu menyusun kalimat.

b. Setelah siswa berlatih mengucapkan beberapa kalimat kemudian mereka membacanya dalam teks. Guru bertugas mengembangkan sebagian ketrampilan membaca dalam hati bagi murid

\footnotetext{
29 Nazri Syakur, Kognitivisme Dalam Metodologi Pembelajaran Bahasa (Yogyakarta PT.Pustaka Insan Madani, 2009), 43
} 
c. Setelaah itu siswa membaca teks dengan Qiroah jahriyah (membaca keras) yang diikuti dengan beberapa pertanyaan seputar teks untk menguatkan pemahaman.

3. Kelebihan metode qiroah menurut Mohammad Makimmudin yaitu:30

a. Siswa terlatih untuk memahami atau menganalisis teks tidak melalui tarjamah

b. Siswa dapat menguasai kosa kata dengan baik dan benar

c. Siswa dapat memahami dengan baik tentang penggunaan nahwu dan shorof

4. Kelemahan metode qiroah menurut Fuad Effendy yaitu: ${ }^{31}$

a. Siswa kurang terampil dalam mengarang bebas

b. Siswa tidak terampil dalam menyimak dan berbicara

c. Siswa akan kurang mampu mengungkapkan gagasan baik dalam bentuk tulisan ataupun secara lisan.

Menurut Munir bahwa pada dasarnya qiroah dibedakan menjadi dua yaitu: qiroah shamitah dan qiroah jahriyah. Pengertian qiroah shamitah (membaca dalam hati) adalah memahami makna yang terkandung di dalam teks bacaan, sedangkan qiroah jahriyah (membaca nyaring) adalah membaca dengan menekankan pada aktifitas anggota bicara seperti bibir atau lisan yang mengeluarkan suara. 32

Munir mengatakan langkah-langkah dalam praktik pembelajaran menggunakan metode Qiroah sebagai berikut: pertama, guru menyiapkan naskah bacaan yang sesuai dengan realitas peserta didik, yakni yang sesuai dengan kemampuan rata-rata peserta didik, sesuai dengan tingkat perkembangan nalar, psikologis, dan tidak terlalu asinng bagi peserta didik. Kedua, guru meminta seluruh peserta didik untuk membaca di dalam hati, kemudian memilih ketepatan harakat dan sambil merenungkan makna yang terkandung. Ketiga, setelah semua peserta didik diperkirakan sudah membaca sekilas, kemudian guru meminta beberapa peserta didik untuk membaca dengan bergilir dan yang lain menyimak secara cermat. Keempat, ketika peserta didik sedang membaca, guru membuat catatan-catatan tentang hasil bacaan, misalnya mengenai kata-kata yang sering dibaca salah, atau huruf-huruf yang dirasa kurang bisa dibaca secara fasih. Kelima, guru membenarkan kata-kata yang salah yang telah dibaca oleh peserta didik sebelumnya. Keenam, setelah itu guru melakuka review dan membuka kesempatan untuk diskusi tanya jawab tentang tema yang telah dibahas tadi.

Dari langkah-langkah pembelajaran metode qiroah diatas, langkah tersebut lebih cocok dipakai pada tingkat mutawasith dan mutaqodim, sebenarnya metode qiroah tersebut bisa dipakai pada tingkatan manapun seperti tingkat mubtadi, mutawasit, dan mutaqodim. Akan tetapi yang

\footnotetext{
${ }^{30}$ Muhammad Makimmudin, Metode Pengajaran......, 52

31 Ahmad Fuad, Metodologi Pengajaran......, 116

32 Munir, Perencanaan Sistem Pengajaran....., 136
} 
membedakan pada tingakatan-tingkatan tersebut yaitu pada tujuan pembelajaran dan prinspi-prinsipnya. Danu Sulaiman mengatakan dalam menggunakan metode Qiroah ini kita lebih memperhatikan cara atau metode bagaimana peserta didik mudah dalam memahami apa yang telah kita jelaskan. Memilih suatu metode juga harus disesuaikan dengan tingkat kemampuan peserta didik, supaya dalam pembelajaran belangsung dapat diikuti dengan baik sampe akhir. Jika metode yang diterapkan tidak sesuai dengan tingkatan kemampuan peserta didik, maka yang terjadi adalah mereka tidak dapat mengikuti pembelajaran dengan baik dan tidak memberikan manfaat apa-apa kepada peserta didik.

\section{b. Metode Guru Diam}

1. Latar belakang metode Guru Diam

Metode guru diam dicetuskan oleh Caleb Gattegno (1972), seorang ahli pengajaran bahasa yang meneraapkan prinsip-prinsip kognitvisme dan ilmu filsafat dalam pengajarannya. Metode ini muncul sekitar tahun 1960-an setelah Audiolingual berkurang popularitasnya di Amerika Serikat dan di beberapa negara di Eropa. Metode ini biasa disebut dengan At-Thariqa Ash-Shamitah.

Wa muna mengatakan dalam mengajarkan metode ini siswa dibiarkan dahulu melakukan kesalahan, sehingga siswa merasa bebas dan tidak tertekan. Dengan demikian akan bereaksi terhadap bahasa yang baru dipelajari tersebut, sebagaimana mereka bereaksi mempelajari bahasa tersebut. ${ }^{33}$

2. Kelebihan metode Guru Diam

a. Berusaha membina pelajar dengan baik pembelajaran bahasa asing dari permulaan seperti memperhatikan, mengawasi dengan baik,memahami, membiarkan, dan mencari solusi masalah serta saling percaya kepada yang lain

b. Berusaha membangun ketrampilan berbahasa sejak awal dengan baik

c. Konfirmasi guru diam sebagian besar meningkatkan daya tarik peserta didik untuk berlatih bahasa.

3. Kekurangan metode Guru Diam

a. Jika melalui metode guru diam ini dalam pembelajaran bahasa asing secara ilmiah akan membebani mereka dalam usaha mengasah bahasa dan mendahulukan untuk mempelajarinya.

b. Metode ini tidak boleh digunakan untuk anak tang belajar pada tingkat mubtadi dan mutawasith

c. Metode diam ini tidak memandang kelemahan pada kelompok maupun individu diantara pemakainya.

\footnotetext{
33 Wa Muna, Metodologi Pembelajaran Bahasa Arab (Yogyakarta: Teras, 2011), 121
} 
Dalam praktik metode guru diam ini sebagai berikut, pertama: para siswa diberikan bacaan untuk dipelajari, dan mereka berusaha untuk mengetahui makna kata-kata yang sulit dari kamus yang terdapat pada bagian akhir kitab atau melalui media umum. Pada tingkat yang sudah maju dapat mengetahuinya dari kamus yang standar. kedua: pada awal pembelajaran, guru membacakan suatu tema kepada peserta didik dengan tenang dan jelas, sedangkan siswa mendengarkan sambil memperhatikan buku mereka. Apabila tema bacaan itu panjang maka cukup diambil separuhnya saja. ketiga: setelah guru menyelesaikan bacaan secara keseluruhan, dalam waktu yang sama siswa membaca dalam hati dan menggaris bawahi kata yang tidak dipahaminya atau pada kalimat yang tidak dimengerti maknanya atau menulis kata-kata tersebut pada buku catatan yang dikhususkan untuk kata-kata dan maknanya yang sulit. Keempat: jika siswa telah selesai membaca, guru mulai menjelaskan katakata atau kalimat yang sulit kepada siswa. Dan mereka mencatat arti katakata yang sulit dibuku catatan. Kelima: setelah selesai menjelaskan, siswa kembali membaca dalam untuk untuk menganalisis pemahaman terhadap tema tersebut. Keenam: setelah proses diatas, guru memulai membaca keras, guru membaca paragraf pertama sekitar empat atau lima baris yang diikuti oleh siswa. Kemudian bacaan tersebut dibaca kembali oleh peserta didik, lalu guru pindah ke paragraf kedua dan selanjutnya dengan sistem yang sama. Ketujuh: pada jam pelajaran, para siswa membaca tema yang lalu dengan bacaan dalam hati kemudian guru mengajukan pertanyaan yang telah dibuat untuk setiap tema kepada mereka. Kemudian guru memilih ssalah satu siswa untuk menjawab pertanyaan secara lisan dan tertulis.

Menurut penulis metode ini lebih cenderung kepada membaca diam atau membaca dalam hati, karena dalam prosesnya para siswa lebih dominannya membaca dalam hati untuk memahami isi bacaan dan mencatat kata-kata yang tidak mengerti maknanya meskipun pada langkah di tahap akhir pembelajarannya siswa mengikuti guru dengan bacaan yang keras. Metode ini cocok digunakan pada tingkat mutaqodim, tingkata ini merupakan tingkatan yang paling tinggi dalam pembelajaran bahasa arab, karena pada tingkat mutaqodim ini seseorang sudah mempunyai kemahiran atau keterampilan dalam berbahasa arab dengan baik dan fasih. Dengan itu peserta didik tidak akan kesulitan lagi dalam memahami bahasa Arab. Karena dalam metode ini peserta didik sudah diminta untuk memahami dan memaknai tema yang telah ditentukan oleh gurunya.

\section{KESIMPULAN}

Dalam pembelajaran bahasa Arab, metode merupakan hal yang sangat diperlukan, karena dengan adanya metode akan memudahkan peserta didik dalam mempelajari bahasa Arab. Kemudian Sebelum menentukan sebuah metode 


\section{R. Umi Baroroh, Fauziyah Nur Rohmawati}

Metode Dalam Pembelajaran Keterampilan Bahasa Arab...

guru harus mengetahui bagaimana kondisi kemampuan peserta didik, dengan adanya metode diharapkan dapat mengantarkan kepada tujuan pembelajaran serta menambah semangat peserta didik dalam belajar. Di dalam pembelajaran bahasa Arab terdapat macam-macam bentuk metode yang ada pada ketrampilan reseptif diantaranya yaitu: metode langsung, metode al-sam'iyah al-syafawiyah (audiolingual), metode qiroah dan metode guru diam. Metode-metode tersebut bisa digunakan dalam pembelajaran bahasa Arab pada keterampilan istima' dan ketrampilan qiroah. 


\section{DAFTAR PUSTAKA}

Abdur Rahman, 'Keterampilan Membaca Dan Teknik Pengembanganya Dalam Pembelajaran Bahasa Arab, Diwan : Jurnal Bahasa Dan Sastra Arab, 2017 Abudin Nata, Filsafat Pendidikan Islam (Jakarta: Logos Wacana Ilmu, 1997)

Acep Hermawan, Metodologi Pembelajaran Bahasa Arab (Bandung, Remaja Rosdakarya, 2011)

Ahmad Fuad Efendy, Metodologi Pengajaran Bahasa Arab (Malang: Misykat, 2012)

Bisri Musthofa dan Abdul Hamid, Metode Dan Strategi Pembelajaran Bahasa Arab (UIN Maliki Press, 2012)

Dahlia, Sri,Urgensi Metode Qiroah Dalam Pembelajaran Bahasa Arab Di PTAI, Arabia, 2013

Farhatul Atiqoh,Teknik Maudhu Usbuiy Sebagai Alternatif Untuk Meningkatkan Penguasaan Keteramilan Reseptif Dan Produktif Bahasa Arab, Universitas Negeri Malang, 2018

Hasan Syaifullah, Teknik Pembelajaran Keterampilan Bahasa Arab (Cirebon: Nurjati Press, 2012)

Imam Makhruf, Strategi Pembelajaran Bahasa Arab (Needs Press, 2009)

Jamhuri, Ketimpangan Komptenesi Santri Dalam Berbahasa Arab (Studi Analisis Pembelajaran Keterampilan Bahasa Arab Reseptif Dan Produktif Di Pondok Pesantren AL-Baqiyatus Shalihat (UIN Sunan Kalijaga, 2018)

Makinuddin, Mohammad,Metode Pengajaran Bahasa,MIYAH : Jurnal Studi Islam, 2017

Muljanto, Pedoman Pengajaran Bahasa Asing (Surabaya CV. Ilmu Surabaya, 1975)

Munir, Perencanaan Sistem Pengajaran Bahasa Arab (Jakarta PT.Fajar Intrapratama Mandiri, 2017)

Nazri Syakur, Kognitivisme Dalam Metodologi Pembelajaran Bahasa(Yogyakarta PT.Pustaka Insan Madani, 2009)

Sari, Alvia Putri Prima,Tinjauan Terhadap Metode Pembelajaran Bahasa Arab: Metode Qawaid\& Terjemah, Metode Langsung, Metode Audiolingual dan Metode Gabungan, Tarbiyatuna, 2018

Suja'i, Inovasi Pembelajaran Bahasa Arab (Semarang: Walisongo Press, 2008)

Sukardi, Metodologi Penelitian Pendidikan: Kompetensi Dan Praktiknya (Jakarta, Bumi Aksara, 2010)

Suyono, Belajar Dan Pembelajaran (Bandung, Remaja Rosdakarya, 2911)

Syaiful Bahri, Strategi Belajar Mengajar (Jakarta: Rineka Cipta, 2010)

Syaiful Musthofa, Strategi Pembelajaran Inovatif (UIN Maliki Press, 2011)

Tarigan, Berbicara Sebagai Suatu Keterampilan Berbahasa (BaNDUNG PT.Angkasa, 2008)

Wa Muna, Metodologi Pembelajaran Bahasa Arab (Yogyakarta: Teras, 2011) 